\title{
Beef Ban in India: A Multi-dimensional Issue
}

\author{
Anam Khan', Taylor Riedel'2, Rabia Hussain ${ }^{3}$, Isha Patel2,"* \\ ${ }^{1}$ Independent Researcher, New Delhi-110046, INDIA. \\ ${ }^{2}$ Department of Pharmacy Practice, Administration and Research, Marshall University School of Pharmacy (MUSOP), \\ One John Marshall Drive, Huntington, WV 25755, US. \\ ${ }^{3}$ School of Pharmaceutical Sciences, Universiti Sains Malaysia, Penang, MALAYSIA.
}

The Economic Times published an article in January 2019, highlighting the increasing problem of stray cattle in rural India. Four years ago, several states in India began making the decree to protect cows from slaughter at the end of their productive lives. ${ }^{[1]}$ The largely Hindu population in India considers cows sacred and does not condone their slaughter.

In 2012, there were only 5 million stray cattle roaming the Indian streets, but now there is an estimated 40 million unproductive cattle at risk of being abandoned. ${ }^{[1]}$ India only has 5,000 shelters, each with a capacity of 200; but these are near enough. ${ }^{[1]}$ Cattle are being abandoned because they are beyond the age of productivity and the cost for a farmer to keep an unproductive cow is Rs. $7500 /$ month. Prior to the beef ban, farmers could sell dried up cows for Rs. 20,000 to Rs. 50,000 each depending on their age. Farmers are facing a severe economic deficit since they can no longer sell their cattle for profit. ${ }^{[1]}$ The abundance of stray cattle has also led to Indians being physically attacked. Cows trespassing on farm land and destroying crops have recently led to them being locked up inside schools and hospitals for containment. ${ }^{[1]}$ Currently, there is much controversy between Indian political parties on resolving the economic and social stress that cow abandonment has caused on several states in India. ${ }^{[2]}$ There has been argument about the former cattle trade being important for the rural economy and necessary to provide revenue for dairy farmers unproductive cattle. ${ }^{[2]}$

The beef ban has also raised serious concerns of malnutrition in children. Cow meat is one of the cheapest sources of protein for the most socially disadvantaged children in India. ${ }^{[3]}$ As a result, more children are now facing a nutritional intake deficit more than before. According to a recent World Bank Report, India now has the highest number of malnourished children. $44 \%$ children aged 5 years old are underweight. ${ }^{[4]}$ Malnourishment can make children vulnerable to infectious diseases which accounts for more than half the mortality in less than 5 year old children. ${ }^{[4]}$

India will not be soon ending the beef ban, so there is discussion about advancement of livestock production by developing nuclear-derived techniques to improve breeding and reproductive management of cattle farms. Due to these advancements, the genetic-makeup of cows will be optimized leading them to produce up to 5 times more milk per cow. ${ }^{[5]}$ With nuclear-derived genetic optimization techniques, fewer cows will be needed to meet the dairy production demands of the population. Although these advances would still not resolve the issue of malnourishment for children, it could lessen the economic burden on farmers by reducing excess stray and nonproductive cattle. ${ }^{[5]}$

While the unwillingness of the Indian government to condone the slaughter of cows is understandable for religious reasons, neither the burden placed on farmers nor the harm caused to Indian children should be ignored. A solution is needed to counter the overabundance of unproductive cattle and the malnutrition issue facing India's young population.

\section{REFERENCES}

1. India's Supreme Court Suspends Ban on Sale of Cows for Slaughter. 2017. Available at: https://www.nytimes.com/2017/07/11/world/asia/india-cowsslaughter-beef-leather-hindu-supreme-court-ban.html.

2. Renu R. Beefban: Impacts and Consequences on second largest nutrition deficit country. 2015. Available at: http://www.indialivetoday.com/beefban-impacts-andconsequences-on-second-largest-nutrition-deficit-country/158163.html.

3. Shoaib D. Between banned beef and expensive dal, how are poor Indians supposed to get enough protein?. 2015. Available at: https://scroll.in/ article/765001/between-banned-beef-and-expensive-dal-how-are-poor-indianssupposed-to-get-enough-protein

4. Save the Children India. Save the Children India: Malnutrition in India Statistics State Wise. 2017. Available at: https://www.savethechildren.in/articles/ malnutrition-in-india-statistics-state-wise

5. Dixit A. Nuclear-Derived Techniques Improve Cattle Productivity and Milk Quality in Cameroon. 2017. [online] laea.org. Available at: https://www.iaea.org/ newscenter/news/nuclear-derived-techniques-improve-cattle-productivity-andmilk-quality-cameroon

Received: 02 March 2020

Accepted: 10 April 2020

*Correspondence to:

Dr. Isha Patel,

Department of Pharmacy Practice, Administration and Research, Marshall University School of Pharmacy (MUSOP), One John Marshall Drive, Huntington, WV 25755, US.

Email: pateli@marshall.edu

Copyright: $($ the author(s),publisher and licensee Indian Academy of Pharmacists. This is an open-access article distributed under the terms of the Creative Commons Attribution Non-Commercial License, which permits unrestricted non-commercial use, distribution, and reproduction in any medium, provided the original work is properly cited. 